\title{
Psychological Determinants of Linguistic Purism: National Identification, Conservatism, and Attitudes to Loanwords
}

\author{
Karolina Hansen ${ }^{1}$ \\ Michał Wypych ${ }^{1}$ \\ Mirosław Bańko ${ }^{1}$ \\ Michał Bilewicz ${ }^{1}$
}

\begin{abstract}
Aversion to loanwords may express itself in various ways: deliberate and motivated by ideology of linguistic purism or more implicit and motivated by the strength of one's national identification and ethnolinguistic vitality. A study of Polish philology students assessed their tendency to choose loanwords versus synonymous native words. The results supported a two-path model of linguistic purism. Social identity (strength of identification) directly predicted avoidance of loanwords, whereas ideological concerns (conservative political views) predicted it indirectly, through purist ideology.
\end{abstract}

Keywords: nationalistic purism, language attitudes, linguistic borrowings, lexical loans, political views

Some individuals treat loanwords as a factor enriching lexicon of a language, others as a necessary evil, still others as a threat that can and should be combatted. These evaluations run along a scale between extreme liberalism and extreme purism, with both liberals and purists frequently voicing their views in emotional ways. This applies not only to discussions among nonspecialists but also to the stances adopted by linguists (Mańczak, 1970; Nieckula, 1987).

Studies more descriptive than evaluative in nature consider purism as a historical and cultural phenomenon, seeing its causes as lying in the social and political situation

\footnotetext{
${ }^{1}$ University of Warsaw, Warsaw, Poland

Corresponding Author:

Karolina Hansen, Faculty of Psychology, University of Warsaw, ul. Stawki 5/7, 00-183 Warszawa, Poland. Email: karolina.hansen@psych.uw.edu.pl
} 
of a given country or language area (Milroy, 2005; Spitzmüller, 2007). Avoidance of loans from other languages can be studied also at the individual level-looking at individuals' decisions to use loanwords versus native words, as a conscious or nonconscious linguistic choice. Such a perspective allows explaining the variability of purist attitudes: under similar conditions some individuals become extreme purists, others exhibit moderate purism, while still others see nothing wrong in borrowing foreign words.

Studying linguistic purism is important at both individual and societal levels. At the individual level, purism can affect the process of language comprehension (Lin, 2006; Martínez, Hikida, \& Durán, 2015). At the societal level, linguistic purism as an ideology is part of the symbolic power and oppression occurring between advantaged and disadvantaged groups - such as in the case of the French language (Bourdieu, 1991; Walsh, 2016).

In the present research, we focus on two social psychological foundations of people's tendency to avoid loanwords: political ideologies (conservative ideologies determining purist approaches to native language) and social identities (national identification as a source of ethnolinguistic vitality).

\section{Linguistic Purism}

Linguistic purism - the usually exaggerated commitment to the idea of "pure" language - has many varieties. The one dealt with in this article is directed against words of foreign origin. This kind of purism - nationalistic purism - is determined by sociopolitical factors, for example, a threat to national identity, which typically results in an increase of purist attitudes (Spitzmüller, 2007). Poland is a case in point: After its partitioning among three neighboring countries at the end of 18th century, speakers of Polish viewed their language as the main factor of their national identity, and this favored a growth of purist attitudes in the following decades. In similar circumstances, nationalistic purism appeared also in other countries (see, e.g., Halldórsson, 1979; Jelínek, 2002; Lipczuk, 2007; Thomas, 1991).

However, sociopolitical factors are not enough to explain the aversion and often hostility to loanwords. Under the same sociopolitical circumstances, some people are more tolerant to loanwords than others. This suggests that some more general political beliefs and ideologies can be responsible for causing this inter-individual variability in purist attitudes. Besides, the way purists justify their attitudes and activities are similar in different countries, despite the differences in their sociopolitical situations. For example, the motivations of German purists in the past (Lipczuk, 2007) were almost identical to those of the purists in Poland. These observations cannot be satisfactorily explained by referring only to the sociopolitical situation of a given country at a given time. More attention and research has been devoted to sociopolitical factors influencing purism, but in the current article, we are looking at less studied psychological determinants of purism.

Proceeding from our assumption of psychological sources of purism, we are cautious when considering how purists themselves justify the sense of their actions. They 
invoke many kinds of arguments, ranging from purely linguistic ones (foreign expressions allegedly ruin the language), to communicative ones (borrowings allegedly hamper communication between people), and all the way to ideological and patriotic ones (Lipczuk, 2007; Nieckula, 1987). These arguments, however, are most likely just manifestations of people's rationalization of their own psychologically rooted attitudes to loanwords. As such, they are partly dependent on psychological factors, not only on the political or ideological ones. Purists are often accused of being intolerant and excessively conservative (Dorian, 1994; Homer, 2005), but to the best of our knowledge, there is a lack of systematic empirical studies on the relationship between linguistic purism and people's individual beliefs such as political conservatism or personal identification with one's nation.

\section{Purist Choices: Identity Versus Ideology}

People's tendency to avoid linguistic loans can be understood as an automatic, spontaneous choice or as a more deliberate expression of purism, a specific ideology that opposes borrowing words from other languages (Milroy, 2005; Spitzmüller, 2007). In the case of spontaneous choice, it can be driven by certain psychological motivations, some of which can be of implicit character (Petty, Fazio, \& Briñol, 2009). In the case of choices driven by ideological purism, they represent more deliberate decisions embedded in a person's worldview, as purism is related to a set of conservative ideological beliefs (Spitzmüller, 2007).

Here we propose a two-path model determining people's individual tendency to avoid linguistic loans. The first source of such tendency is the purist ideology embedded in a broader structure of conservatism (Spitzmüller, 2007). We propose that the conservatives' preference for order, structure, and closure, as well as their respect for tradition and resistance to change (Jost, Glaser, Kruglanski, \& Sulloway, 2003), would motivate ideological opposition to borrowings from other languages. It is wellestablished that conservatism is reflected in specific language choices (e.g., a preference for usage of nouns vs. adjectives; Cichocka, Bilewicz, Jost, Marrouch, \& Witkowska, 2016). We propose that it might as well motivate people's tendency to avoid loanwords.

The second source of avoidance of loanwords that we propose is based on more implicit social identity-based processes (Tajfel \& Turner, 1979). The preference for native words over loanwords could be a reflection of in-group bias that is particularly visible among highly identified group members. In the domain of language use, this process can be related to ethnolinguistic vitality, which is understood as a group's ability to maintain and protect its culture and linguistic identity (Giles, Bourhis, \& Taylor, 1977). The concept of ethnolinguistic vitality has been used to explain how groups maintain their language versus accommodate and shift toward other languages. This process is motivated by social identity needs such as strivings to maintain a distinctive ethnic or national identity (but not necessarily intergroup biases). Ethnolinguistic vitality affects people's willingness to acquire second language (Giles \& Byrne, 1982) as well as to maintain their own language (Giles \& 
Johnson, 1987). Based on that, one may suppose that similar identity-driven processes could lead to loanwords avoidance.

When talking about identity-level motivations, it should be differentiated between two kinds of national identity: healthy and narcissistic (Cichocka, 2016). These terms refer to more general distinctions between defensive forms of national attachment (i.e., nationalism, in-group glorification, blind patriotism) and secure forms of national attachment (i.e., constructive patriotism, in-group attachment; Roccas, Klar, \& Liviatan, 2006; Schatz, Staub, \& Lavine, 1999). Healthy identification is a secure form of attachment to one's ethnic or national group (Cameron, 2004). Narcissistic identity is an emotional investment in an unrealistic belief about the greatness of one's group (Golec de Zavala, Cichocka, \& Bilewicz, 2013). Both of them could be plausible causes of loanwords avoidance: secure identification due to the ethnolinguistic vitality strivings and collective narcissism due to the possible prejudicial nature of linguistic purism.

\section{Current Research}

The present study was designed to assess people's tendency to avoid loanwords and to establish potential psychological factors responsible for such purist behavior. In order to test the two-path model of loanword avoidance, we assessed both ideological beliefs (political conservatism, purist ideology) and identity motives (strength of identification—-both secure and narcissistic).

Polish philology students were presented with a task of choosing between two synonymous words (a native word vs. an established loanword) in order to assess their avoidance of loanwords. Questionnaire measures of identification and ideologies allowed explaining participants' tendency to avoid loanwords.

We hypothesized that people holding more conservative political views would more strongly endorse purist ideology and this ideology would motivate their avoidance of loanwords. At the same time, we hypothesized that people highly identifying with their group (both in a secure way and in a narcissistic way) would avoid loanwords even in an implicit, unreasoned way-without mediation of purist ideology.

\section{Selection of Linguistic Loans}

Because one of the factors hypothetically contributing to a negative view of loanwords is their foreign form, we limited our study to "borrowings proper," setting aside loan translations and semantic loans. Moreover, we only included loanwords with foreign origins still visible to nonspecialists. In Polish the majority of loans come from nonSlavic languages, they sound differently, and they are easy to recognize as loans. ${ }^{1}$ To indicate whether it was clear which words were loans, we used our knowledge, intuition, and a small pretest $(N=5)$ conducted on people unaware of the goal of the study.

We also controlled for the influence of possible perceptual features of loanwords versus native words. As a proxy of these, we used the length of each word and the number of consonants and vowels. We also tried to balance the frequencies of loans 
Table I. Descriptive Statistics for the Chosen Loanwords and Native Words.

\begin{tabular}{lcccc}
\hline & $\begin{array}{c}\text { Average number } \\
\text { of letters }\end{array}$ & $\begin{array}{c}\text { Average number } \\
\text { of consonants }\end{array}$ & $\begin{array}{c}\text { Average number } \\
\text { of vowels }\end{array}$ & $\begin{array}{c}\text { Average frequency } \\
\text { (per million words) }\end{array}$ \\
\hline Native words & 9.30 & 5.30 & 3.30 & 27.19 \\
Loanwords & 8.50 & 5.50 & 2.90 & 11.50 \\
\hline
\end{tabular}

versus native words. Native words are usually more common than synonymous loans. Also in our study it was the case, but the difference was relatively subtle (Table 1). In total 10 loan-native pairs were used in the study.

\section{Method}

\section{Participants}

Participants of the study were 186 first-year Polish philology students (age range $=17$ to $41, M=20.05, S D=2.56,156$ women, 25 men, $5 \mathrm{NA}$ ). Most (174) participants were of Polish nationality, three of double (Polish plus other) nationality, five were Ukrainian, and four did not provide nationality information. As the foreign-born participants identified with Poland to a similar extent $(M=3.35, S D=0.88)$ as Polish participants $(M=3.44, S D=0.92)$, we did not exclude them from the analyses.

\section{Procedure and Measures}

The study was conducted after a short knowledge quiz at the end of the semester and was presented as having two parts. The first contained a scale of national identification with Poland ( $\alpha=.89$; Bilewicz \& Wójcik, 2010; Cameron, 2004) and of collective narcissism regarding Poland ( $\alpha=.86$; Golec de Zavala et al., 2013). ${ }^{2}$ Responses were indicated using Likert-type scales ranging from $1=$ not at all to $5=$ very much. In the second part, participants were presented with a list of 17 word pairs. For each pair participants were asked to choose which word from the pair they liked more. They marked their answers on a scale ranging from $1=$ definitely the first word to $5=$ definitely the second word with $2 / 4=$ rather the first/second word and $3=$ both to the same extent. As the participants were philology students and could be expected to have some linguistic knowledge, they were instructed that there were no right or wrong answers and were asked to mark their first intuitive reaction. There were 10 loan-native pairs and seven distractor pairs (four native-native, three loan-loan). The order of the target and distractor pairs was randomized. The order of words within all pairs was counterbalanced. Answers regarding the 10 loan-native pairs were averaged to create a purist choice measure $(\alpha=.45)$, with higher scores indicating most purist choices.

Afterwards, participants declared how much they agreed (scale: $1=$ strongly disagree to $5=$ strongly agree $)$ with four items measuring declarative purism $(\alpha=.75$; e.g., "Loanwords should be avoided"), indicated their political beliefs ( $1=$ definitely conservative to $5=$ definitely liberal), ${ }^{3}$ and answered a few demographic questions. 
Table 2. Correlations Between Dependent Variables.

\begin{tabular}{lcccc}
\hline & Conservatism & Identification & Narcissism & Declared purism \\
\hline Conservatism & & & & \\
Identification & $.38^{* * *}$ & & & \\
Narcissism & $.23^{* *}$ & $.59 * * *$ & & \\
Declared purism & $.24^{* *}$ & .12 & .06 & $.18^{*}$ \\
Purist choices & .11 & $.20^{* *}$ & .06 & \\
\hline
\end{tabular}

Note. Identification $=$ secure identification; Narcissism $=$ collective narcissism .

$*_{p}<.05 . *_{p}<.01$. *** $p<.001$.

\section{Results}

\section{Correlations}

In order to examine how conservatism, secure national identification, and collective narcissism are related to purist declarations and to purist choices, we ran a correlational analysis (Table 2). First, the two types of identification (i.e., secure national identification and collective narcissism) were positively correlated. Second, purist declarations and purist choices were only weakly correlated. Third, conservative beliefs were related to all other variables except for purist choices; secure national identification was related to all other variables except for purist declarations. Collective narcissism was not related to any of the two types of purism.

\section{Indirect Effects}

In order to validate the two-path hypothesis, we tested an indirect effects model of relationships between secure identification, conservatism, and two types of purism. As the correlational analyses showed that only secure identification was correlated with purism, but collective narcissism was not, we decided not to use collective narcissism as a potential predictor in the proposed model.

We tested our model (Figure 1) using Model 4 in the SPSS macro PROCESS (Hayes, 2013), with 95\% bias-corrected (BC) bootstrapped confidence intervals (CIs) based on 5,000 bootstrap samples. As in the correlational analysis, conservatism was related to secure identification, $b=.28, S E$ (boot) $=.05, \mathrm{CI}=[.18, .38]$. Furthermore, secure identification predicted purist choices, $b=.11, S E$ (boot) $=.05$, $\mathrm{CI}=[.01, .21]$. Conservatism did not directly lead to purist choices, $b=.00, S E$ (boot) $=.04, \mathrm{CI}=[-.07, .07]$, but it did so indirectly, $b=.01, S E($ boot $)=.02, \mathrm{CI}=[.001$, $.05]$ via declarative purism. This indirect effect showed that the more participants endorsed conservatism, the more they declared that loanwords are undesirable in the Polish language, $b=.16, S E($ boot $)=.05, \mathrm{CI}=[.06, .25]$, and furthermore, the more they declared that loanwords are undesirable, the more they preferred native synonyms, $b=.11, S E$ (boot) $=.05, \mathrm{CI}=[.002, .21]$. In sum, the analysis showed that there are two pathways to purist choices: (1) a direct one from secure national 


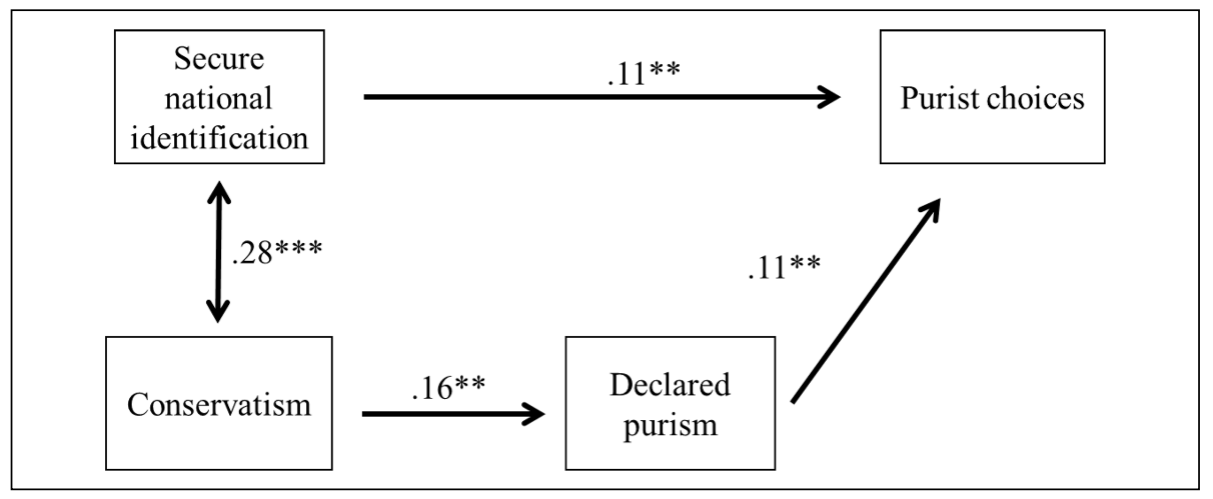

Figure I. Two paths to purist linguistic choices: (I) a direct one from secure national identification and (2) an indirect one from conservatism through beliefs that loanwords damage one's language.

$* * p<.01 . * * * p<.001$.

identification and (2) an indirect one from conservatism through beliefs that loanwords damage the Polish language.

In order to increase confidence in the causal direction of the proposed model, we tested alternative models where the elements of the model were placed in a different order. The results showed that neither the model with identification and conservatism in reversed order (indirect effect, $b=.01, S E($ boot) $=.01, \mathrm{CI}=[-.001, .04]$ ) nor the one with purism and conservatism in reversed order (indirect effect, $b=.00, S E($ boot) $=$ $.01, \mathrm{CI}=[-.02, .03])$ showed significant indirect effects. Therefore, we can cautiously assume that the relationships in the first model are causal.

\section{Discussion}

The current study showed a two-path model of linguistic purism. The tendency to avoid loanwords was directly related to social identity concerns (strength of identification) and to purist ideology. Additionally, we found an indirect effect of conservative world-view on avoidance of loanwords through purist ideology. Of the two forms of identification, it was the secure one rather than the narcissistic one that played an important role in people's choices of native words over loanwords.

This pattern of results suggests that people's attitudes to loanwords should not be viewed as a form of national defensiveness, typical for narcissistic forms of in-group attachment (Cichocka, 2016). People who decide to use native language synonyms rather than loanwords do so even without a clear purist ideology - as the effects of identification were not mediated by purist ideology. This suggests that everyday purist choices are driven by automatic social identity-based processes (Tajfel \& Turner, 1979). They are a consequence of ethnolinguistic vitality strivings - a healthy need to protect local culture and distinctive linguistic identity - rather than a prejudicial 
obsession about in-group image reflected in the narcissistic identity. In the current study, language and nation were strongly overlapping, but in cases of many postcolonial countries language spans several nations. Future research could address how in such contexts national identity (and other factors, like identification as a speaker of the language) are related to linguistic purism.

In the current study, the opposition to loanwords can be partly attributed to ideology of purism. People holding such an ideology choose deliberately not to use loans from other languages due to their conservative worldviews. Conservatives are more conventionalist (adhering to the established social norms; Jost et al., 2003) and lower in integrative complexity (ability to take multiple perspectives and acceptance of different views of reality; Tetlock, 1983). Both of these facts are potential reasons why conservatives more often than liberals endorse linguistic purism. Future studies should establish the exact reasons for conservative purist attitudes.

Previous sociolinguistic analyses of linguistic purism suggested that purist ideology is a part of larger cultural debates about nationalism, conservatism, and historical issues (Homer, 2005; Milroy, 2005; Spitzmüller, 2007; Thomas, 1991). Our study is probably the first to analyze individual-level predictors of people's opposition to loanwords. Using statistical analysis of questionnaire results, we confirmed that ideologies and identities play a crucial role in linguistic purism also at the individual level. Although conservatism is related to strong national identification (Haidt, Graham, \& Joseph, 2009), present research suggests that conservatism and identification constitute two distinctive motivators of linguistic purism. Still, there is a need for more elaborate experimental and longitudinal studies that would clearly determine the exact causality between identities, ideologies, and loanwords aversion. We believe that the present study is a stepping stone in our understanding of linguistic purism, a phenomenon severely understudied in the psychology of language and in social psychology.

Linguistic purism influences second language teaching (Lin, 2006; Martínez et al., 2015), as well as contributes to societal inequalities by being a part of the symbolic dominance of advantaged groups over disadvantaged groups (Bourdieu, 1991; Walsh, 2016). Our greater understanding of the motivations of linguistic purism can help diminish these social inequalities and tackle obstacles in language teaching.

\section{Acknowledgments}

We would like to thank the editor and two anonymous reviewers for helpful comments on the earlier draft of this article.

\section{Declaration of Conflicting Interests}

The author(s) declared no potential conflicts of interest with respect to the research, authorship, and/or publication of this article.

\section{Funding}

The author(s) received no financial support for the research, authorship, and/or publication of this article. 


\section{Notes}

1. Word-pairs used were the following: kompleksowy-catościowy, lingwistycznyjęzykoznawczy, identyczny-jednakowy, torsje-wymioty, specyficzny-swoisty, adekwatnyodpowiedni, abstrakt-streszczenie, display-wyświetlacz, design-wzornictwo, and fan-wielbiciel.

2. For exploratory reasons we also measured the need for cognitive closure, ability to achieve closure, and (at the end) preferred approach to country's economy (free market vs. welfare state). None of these proved related to any of the dependent variables and will not be reported.

3. The full question stated, "Speaking of views in the sphere of morality/customs (e.g., divorce, homosexuality, or abortion), people refer to themselves as 'conservative' or 'liberal.' Which place on the scale below best describes your beliefs?"

\section{References}

Bilewicz, M., \& Wójcik, A. (2010). Does identification predict community involvement? Exploring consequences of social identification among the Jewish minority in Poland. Journal of Community \& Applied Social Psychology, 20, 72-79.

Bourdieu, P. (1991). Language and symbolic power. Cambridge, MA: Harvard University Press.

Cameron, J. E. (2004). A three-factor model of social identity. Self and Identity, 3, 239-262.

Cichocka, A. (2016). Understanding defensive and secure in-group positivity: The role of collective narcissism. European Review of Social Psychology, 27, 283-317.

Cichocka, A., Bilewicz, M., Jost, J. T., Marrouch, N., \& Witkowska, M. (2016). On the grammar of politics - or why conservatives prefer nouns. Political Psychology, 37, 799-815.

Dorian, N. C. (1994). Purism vs. compromise in language revitalization and language revival. Language in Society, 23, 479-494.

Giles, H., Bourhis, R. Y., \& Taylor, D. M. (1977). Towards a theory of language in ethnic group relations. In H. Giles (Ed.), Language, ethnicity, and intergroup relations (pp. 307-348). London, England: Academic Press.

Giles, H., \& Byrne, J. L. (1982). An intergroup approach to second language acquisition. Journal of Multilingual and Multicultural Development, 3, 17-40.

Giles, H., \& Johnson, P. (1987). Ethnolinguistic identity theory: A social psychological approach to language maintenance. International Journal of the Sociology of Language, 68, 69-99.

Golec de Zavala, A., Cichocka, A., \& Bilewicz, M. (2013). The paradox of in-group love: Differentiating collective narcissism advances understanding of the relationship between in-group and out-group attitudes. Journal of Personality, 81, 16-28.

Haidt, J., Graham, J., \& Joseph, C. (2009). Above and below left-right: Ideological narratives and moral foundations. Psychological Inquiry, 20, 110-119.

Halldórsson, H. (1979). Icelandic purism and its history. Word, 30, 76-86.

Hayes, A. F. (2013). Introduction to mediation, moderation, and conditional process analysis: A regression-based approach. New York, NY: Guilford Press.

Homer, K. (2005). Reimagining the nation: Discourses of language purism in Luxembourg. In N. Langer \& W. V. Davies (Eds.), Linguistic purism in the Germanic languages (pp. 166185). Berlin, Germany: de Gruyter.

Jelínek, M. (2002). Purismus [Purism]. In P. Karlík, M. Nekula, \& J. Pleskalová (Eds.), Encyklopedický slovník češtiny [Encyclopedic dictionary of Czech]. Prague, Czech Republic: NLN. 
Jost, J. T., Glaser, J., Kruglanski, A. W., \& Sulloway, F. J. (2003). Political conservatism as motivated social cognition. Psychological Bulletin, 129, 339-375.

Lin, A. (2006). Beyond linguistic purism in language-in-education policy and practice: Exploring bilingual pedagogies in a Hong Kong science classroom. Language and Education, 20, 287-305.

Lipczuk, R. (2007). Geschichte und Gegenwart des Fremdwortpurismus in Deutschland und Polen [Past and present of the nationalistic purism in Germany and Poland]. Frankfurt am Main, Germany: Peter Lang.

Mańczak, W. (1970). Z zagadnień językoznawstwa ogólnego [Issues in general linguistics]. Wrocław, Poland: Ossolineum.

Martínez, R. A., Hikida, M., \& Durán, L. (2015). Unpacking ideologies of linguistic purism: How dual language teachers make sense of everyday translanguaging. International Multilingual Research Journal, 9, 26-42.

Milroy, J. (2005). Some effects of purist ideologies on historical descriptions of English. In N. Langer \& W. Davies (Eds.), Linguistic purism in the Germanic languages (pp. 324-342). Berlin, Germany: de Gruyter.

Nieckula, F. (1987). O tzw. kryterium narodowym poprawności językowej [On the so-called national criterion of language correctness]. Rozprawy Komisji Jezzkowej (Vol. 15, pp. 543). Wrocław, Poland: Wrocławskie Towarzystwo Naukowe.

Petty, R. E., Fazio, R. H., \& Briñol, P. (2009). The new implicit measures: An overview. In R. E. Petty, R. H. Fazio, \& P. Briñol (Eds.), Attitudes: Insights from the new implicit measures (pp. 3-18). New York, NY: Psychology Press.

Roccas, S., Klar, Y., \& Liviatan, I. (2006). The paradox of group-based guilt: modes of national identification, conflict vehemence, and reactions to the in-group's moral violations. Journal of Personality and Social Psychology, 91, 698-711.

Schatz, R. T., Staub, E., \& Lavine, H. (1999). On the varieties of national attachment: Blind versus constructive patriotism. Political Psychology, 20, 151-174.

Spitzmüller, J. (2007). Staking the claims of identity: Purism, linguistics and the media in post1990 Germany. Journal of Sociolinguistics, 11, 261-285.

Tajfel, H., \& Turner, J. C. (1979). An integrative theory of intergroup conflict. In Austin W. G. Austin \& S. Worchel (Eds.), The social psychology of intergroup relations (pp. 33-47). Monterey, CA: Brooks-Cole.

Tetlock, P. E. (1983). Cognitive style and political ideology. Journal of Personality and Social Psychology, 45, 118-126.

Thomas, G. (1991). Linguistic purism. London, England: Longman.

Walsh, C. (2016). Gender and discourse: Language and power in politics, the church and organisations. New York, NY: Routledge.

\section{Author Biographies}

Karolina Hansen is an assistant professor at the Psychology Faculty of the University of Warsaw. Her research interests are in the fields of social psychology, sociolinguistics, and cross-cultural psychology. They include topics such as language and accent attitudes, stereotyping, gender-fair language, linguistic biases, and cross-cultural differences in social cognition.

Michal Wypych is a student at the Psychology and Philosophy Faculties of the University of Warsaw. His interests are in the fields of self-dehumanization processes, social psychology of intergroup relations, and the concept of affect in philosophy. 
Mirosław Bańko is a professor at the Faculty of Polish Studies, University of Warsaw, and the head of the Institute of the Polish Language. Among his areas of study is the perception of loanwords and the form-meaning relationship as a potential factor affecting the process of loanword adaptation.

Michal Bilewicz is a professor at the Psychology Faculty of the University of Warsaw and a director of the Center for Research on Prejudice at the same institution. He is interested in social psychology of intergroup relations, dehumanization and infrahumanization processes, contact hypothesis and prejudice reduction, as well as linguistic aspects of discrimination. 